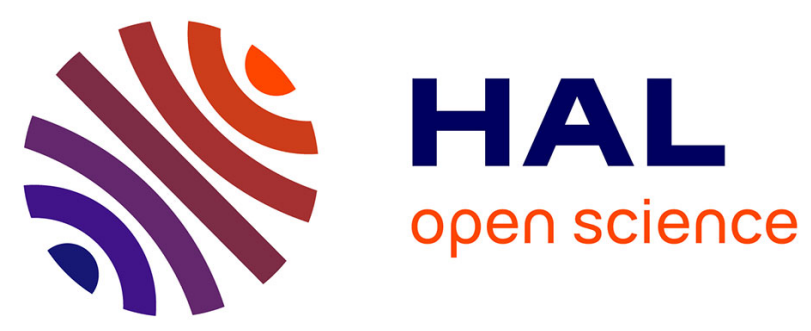

\title{
Contribution to knowledge of the Lakes of Ounianga by bathymetry and physicochemistry
}

\author{
Bourma Arrakhais Abakar, Hamit Abderamane, Moussa Abderamane, \\ Béatrice Ketchemen-Tandia, Abdalah Mahamat Nour
}

\section{- To cite this version:}

Bourma Arrakhais Abakar, Hamit Abderamane, Moussa Abderamane, Béatrice Ketchemen-Tandia, Abdalah Mahamat Nour. Contribution to knowledge of the Lakes of Ounianga by bathymetry and physicochemistry. International Journal of Water Resources and Environmental Engineering, 2017, 9 (10), pp.218-225. 10.5897/IJWREE2017.0735 . hal-03356255

\section{HAL Id: hal-03356255 \\ https://hal.science/hal-03356255}

Submitted on 27 Sep 2021

HAL is a multi-disciplinary open access archive for the deposit and dissemination of scientific research documents, whether they are published or not. The documents may come from teaching and research institutions in France or abroad, or from public or private research centers.
L'archive ouverte pluridisciplinaire HAL, est destinée au dépôt et à la diffusion de documents scientifiques de niveau recherche, publiés ou non, émanant des établissements d'enseignement et de recherche français ou étrangers, des laboratoires publics ou privés. 
Vol. 9(10), pp. 218-225, October 2017

DOI: 10.5897/IJWREE2017.0735

Article Number: 90E4D1665957

ISSN 2141-6613

Copyright (c) 2017

Author(s) retain the copyright of this article

http://www.academicjournals.org/IJWREE
International Journal of Water Resources and Environmental Engineering

\title{
Contribution to knowledge of the Lakes of Ounianga by bathymetry and physicochemistry
}

\author{
Arrakhais Abakar Bourma ${ }^{1}$, Abderamane Hamit ${ }^{2}$, Moussa Abderamane ${ }^{2}$, \\ Beatrice Ketchemen-Tandia ${ }^{1}$ and Mahamat NourAbdalah ${ }^{2}$
}

${ }^{1}$ Department of Earth Sciences, Faculty of Sciences, University of Douala, P. O. Box 14157, Douala, Cameroon.

${ }^{2}$ Department of Geology, Faculty of Exact and Applied Sciences, University of N'djamena, P. O. Box 1027, N'djamena, Chad.

Received 15 June, 2017; Accepted 22 August, 2017

This work aimed to contribute to knowledge improvement of the great Lake ecosystems of Chad, precisely that of the Lakes of Ounianga using bathymetric statements on water levels and the in situ analysis of physicochemical parameters of the lake's waters. Bathymetric surveys facilitated characterization of the morphology of the bottom of the lakes with depths that vary from 0 to $-27 \mathrm{~m}$ and 0 to $-5.7 \mathrm{~m}$ for Yoan and Teli Lakes, respectively. With regards to water physio-chemistry, the temperature of the Teli Lake water measuring up to $0.5 \mathrm{~m}$ varied from 20.8 to $36^{\circ} \mathrm{C}$, while that of Lake Yoan varied from 10.50 to $32.90^{\circ} \mathrm{C}$, with an average of 22 and $27^{\circ} \mathrm{C}$. The conductivity values oscillated between 69 and $111,700 \mu \mathrm{S} / \mathrm{cm}$ for the Lake Teli and 100 to $64,000 \mu \mathrm{S} / \mathrm{cm}$ for the Lake Yoan. This document illustrates the techniques used in the investigation of a lake whose study constitutes a wide field of continental hydrology.

Key words: Ecosystem, lakes, bathymetry, physio-chemistry, Ounianga, Chad.

\section{INTRODUCTION}

Bathymetry is defined as measurement of the depth of a water body through survey and processing of the corresponding data in order to determine the configuration of its base. It is a factor which determines the operation and quality of the lake ecosystems (Demers and Arvisais, 2011; Ostendorp, 2004). Indeed, the morphological characteristics of the lakes determine the thermal mode of stratification and thus indirectly determine the circulation of water, the suspended matter and the nutriments (Bragg et al., 2003; De Bortoli and Argillier, 2006). The variation in depth influences the availability of habitats while acting on the relative surface of the littoral zone and the availability of light for the process of stratification. Furthermore, it gives information on the distribution of sediments. More generally, bathymetry contributes to the apprehension of factors which determines the distribution of the aquatic communities: depths, pressures, temperatures, effects on

*Corresponding author. E-mail: abderamanehamit@gmail.com.

Author(s) agree that this article remain permanently open access under the terms of the Creative Commons Attribution License 4.0 International License 
the currents.

It is probably due to all these reasons that the French co-operation via its project Great Lake Ecosystems of Chad (GELT) aims at including/understanding the diversity of Chad ecosystem, which indeed contributes to the richness of the country. This system studies five Lakes, of which some are at the heart of the desert; as is the case with the Lakes of Ounianga. Although located in a tourist area, recognized as a United Nations Educational, Scientific and Cultural Organization (UNESCO) world heritage site, Ounianga Lakes were not the subject of systematic studies for many years. However, these Lakes are of a great scientific, tourist and economic interest together with their specificity of operation within the great Lakes ecosystems of Chad. Capot-Rey (1961) and Tubiana (1997) worked on the determination of the vegetation cover of Ounianga and Sérir Lakes. Kuper and Kröpelin (2006), Kröpelin (2007a, b), and Kröpelin et al. (2008) studied the sediments deposits of the Lake Yoan, which are of great interests in the reconstitution and evolution of the climatic and environmental conditions on a worldwide scale, while Burgis and Symoens (1987) described and gave brief overview of all the Lakes existing in the Sahara.

This paper is the first investigation of continental hydrology in the study zone which consists of 11,224 inhabitants on a surface of 62.408 ha with tourism, agriculture and breeding as principal economic activities (INSEED, 2012). It aims at contributing to the knowledge improvement of the great lake ecosystems of Chad, precisely that of Lakes of Ounianga, in order to better understand: (i) their structure, (ii) variation of the lakes depth, and (iii) physical properties of the lakes waters. Bathymetric measurements make it possible to partly answer the elements required in the last two points, which are the depth and lakes structure. Bathymetry is thus a criterion impossible to circumvent for description of morphology of the water levels by means of data collection during the Ounianga mission (project GELT). A bathymetric survey involves the use of bathymetric charts, consideration of current volume and use of hypsometric profiles to determine the bathymetric provinces. The in situ analysis of the physicochemical parameters will as a result include charts of space distribution of the temperature and conductivity according to the depth. This document shows the techniques of investigation in the case of a lake whose study constitutes a wide field of continental hydrology.

\section{STUDY AREA AND METHODOLOGY}

\section{Localization, geological and climatic tallies}

Located in the north-east of Chad, between Ennedi and Tibesti (Figure 1), the Lakes of Ounianga, which are a series of Lakes, ponds and marshes, are grouped into two sets known as: Ounianga Kebir and Ounianga Seghr/Serir. The distance between the two sets is about sixty kilometers by road (approximately $40 \mathrm{~km}$ on space, between Lake Yoan and Lake Teli). The two groups of lakes, Ounianga Kebir and Ounianga Serir, consist of a total of eighteen lakes of which four are Ounianga Kebir and fourteen are Ounianga Serir. The first group of lakes (Figure 1B), Ounianga Kebir, consists of four lakes (Yoan, Uma, Mioji and Forodone) of which the principal lake, known as Yoan, extends on a surface from 358 ha (approximately $3.58 \mathrm{~km}^{2}$ ). The second group of lakes (Figure 1C), Ounianga Serir, consists of fourteen lakes (Ardjou, Abromé, Agouta, Bedrim, Boukou, Boul, Hogou, Edem, Melekoui, Dierké, Djara, Tarem, Teli, Tibitchei) separated by dunes. They are staged from 359 to $345 \mathrm{~m}$ of altitude, covering a surface of less than $10 \mathrm{~km}^{2}$, within the center of the basin is the widest Lake Teli which is low and around $4.4 \mathrm{~km}^{2}$. This present document is limited to the two principal lakes which are the Lakes Yoan and Teli.

The climate of this zone is hyper arid which is marked by long periods of dryness and the absence of a rainy season. Precipitations are always lower than $25 \mathrm{~mm}$ with sometimes several consecutive years without any precipitation. An extraordinary intensity of evaporation of $7,800 \mathrm{~mm}$ per annum, a very strong thermal amplitude (the difference in temperature between the hottest month (May) and the coldest month (January) which is higher than $30^{\circ} \mathrm{C}$ with extreme amplitudes reaching up to $47^{\circ} \mathrm{C}$, are all characteristics of this zone (Capot-Rey, 1961). Lastly, most of the year, this region sometimes undergoes violent winds of northeastern direction, which generates a displacement of barchans and various stranding. The various lake sets of Ounianga occupy the depressions of tectonic origin, dug and modelled by old river erosions and wind mills (Krôpelin, 2007b). Although they are no longer connected to a hydrographic network, these lakes still exist under this extreme climate thanks to the great number of sources, with diffused flow, which feed them along their banks. These sources correspond to resurgences of the fossil sheet of water of the vast aquifer of the continental interlayer. They ensure that water levels of the lakes are nearly constant, with fluctuations of approximately $0.5 \mathrm{~m}$ according to the seasons, while for the Lake Yoan, a maximum water level in March and April and a minimum in September and October is evident (Capot-Rey, 1961; Jungraithmayr et al., 1997). The whole of the Lakes Ounianga Sérir, located in a clay origin of broad depression $10 \mathrm{~km}$, is of hydrological characteristics (Krôpelin, 2007b; UNESCO, 2011). With the exception of the Lake Teli, which is particularly dirty, all other surrounding lakes have fresh water or brackish (Van Bocxlaer et al., 2011), and are partly or completely covered with reeds (Eragrostis bipmnata). Finally, contrary to the water discharge system of the close lakes, the water of Lake Teli is particularly salted because of the intense evaporation to which it is subjected.

The geological make-up of the zone under study shows that majority of the formations belong to the Continental guide, also called Grès of Nubie (Hissene, 1986). The lakes are located in a monotonous formation of white likings similar to kaolin, which are finely light and strongly fractured, called Lake formation of which the thickness recognized by drilling is about $120 \mathrm{~m}$ for Lake Ounianga Kébir. The argillaceous sandstones and sandstones cover this series, which levels primarily in the depressed zones; this is the formation of Ounianga, recognizable from its pink color. The formation of the lakes and that of Ounianga are probably of Jurassic age (Wolff, 1964; Hissene, 1986).

The sandstones of Nubie contain a general aquifer drained on the one hand towards the North (zone of the palm plantations of Koufra) and on the other hand, towards the lowest altitude of Chad. The hydraulic load is such that it provides artesian water in the topographic depressions: Koufra and Faya. The water is naturally soft, are salted (the common facies is carbonated sodic) in the sectors where the surface of the tangent tablecloth surface of the ground, particularly in the low depth and deep water as detected in drillings undertaken at Faya-Largeau (4 drillings carried out in 1961 - 1962 between 155 and $350 \mathrm{~m}$ ) and the surveys conducted with Ounianga. 


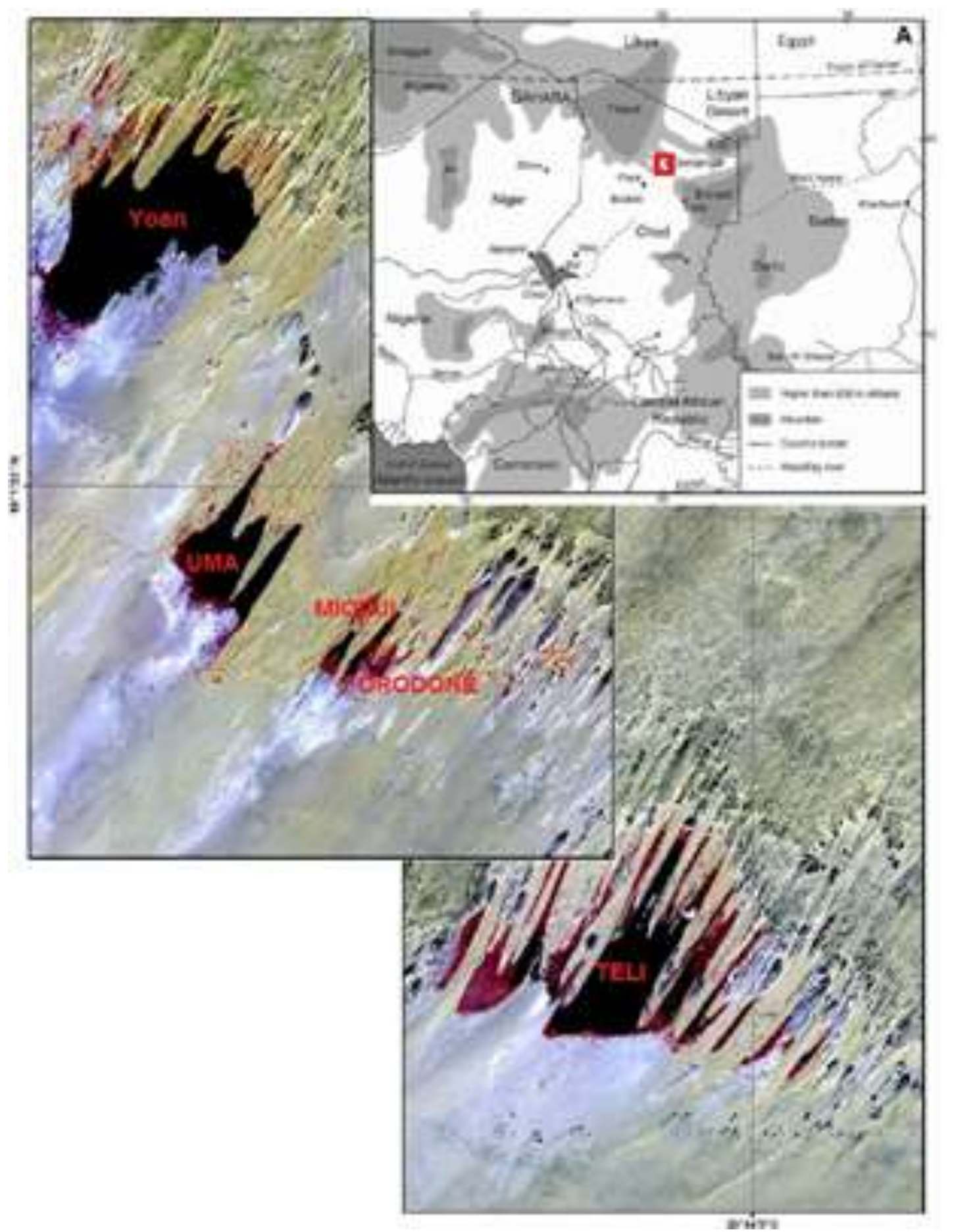

Figure 1. Chart of Northern Africa exchange $(A)$ with localization of the zone of Ounianga in the NorthEast of Chad located between the mountainous solid mass of Tibesti and Ennedi (Van Bocxlaer et al., 2011); the satellite image of the spot assembling (B) Ounianga Kebbir and (C) Serir.

\section{Ground data}

\section{Surveys and bathymetric treatments of probes}

The bathymetric data of the Lakes Yoan (Ounianga Kebir) and Teli (Ounianga to Serir) were collected via bathymetric surveys, carried out using an electronic echo sensor of Garmin type, series 70, coupled with a system of localization by saTelite simultaneously (Global positioning system - GPS). The transducer (left transmitting the sonar) is fixed to the back of the boat such that it is constantly immersed in water. The bathymetric surveys were carried out by making turns or circle initially to the periphery (Figure 2) of the Lake 

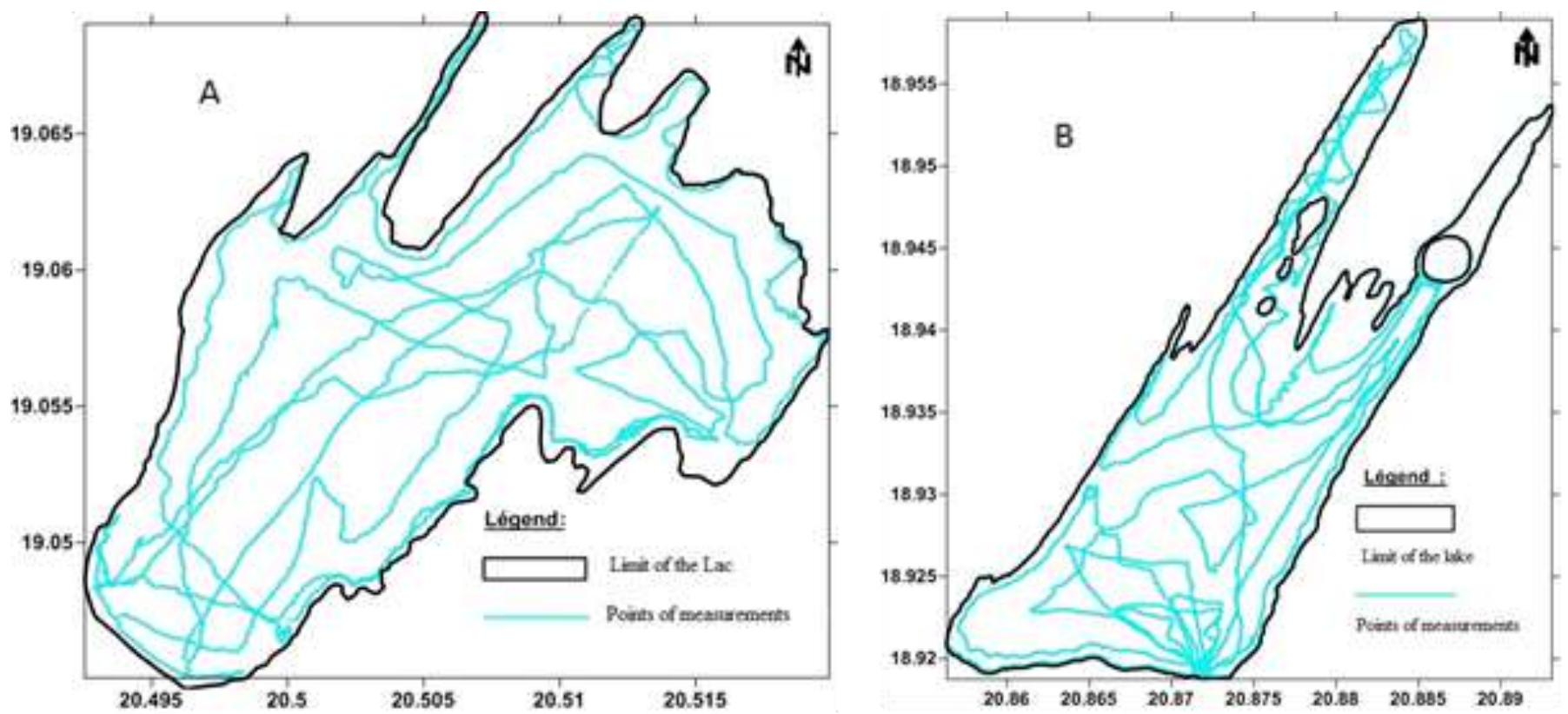

Figure 2. Localization of the points of measurements (way carried out).

and while evolving gradually to the center, the acquisition of the data is automatic on a step of regular time (each $10 \mathrm{~s}$ ). This resolution was applied to the unit of the Lake. Thereafter, the bathymetric data were analyzed and transcribed with the aim of establishing the isobaths of depth of the water level. The depths obtained thus represent measurement between the position of the transducer of the echo sensor and the water-sediment interface. No correction of data was made in order to determine the real depth at each point, since the water of the lakes was not disturbed. However, despite all the precautions taken on the ground, the echo sensor does not measure depth lower than $0.6 \mathrm{~m}$. To mitigate the null bathymetric data $(0 \mathrm{~m})$ which is perhaps also due to a boiling of the outboard motor and the bad alignment of probe etc, this vacuum was filled using the in situ inspections and a graduated pole of a value of $0.5 \mathrm{~m}$ and a value of zero was imposed for the contour of the Lake. More than 9,069 points for the Yoan Lakes and 7,049 points for Teli of echosondeur were thus collected. Each one of these points is composed of co-ordinates $X$ (longitude), $Y$ (latitude) and Z (altitude or depth in this case). The bathymetric chart was generated thanks to the Surfer modeling software of surface with the method of Krieger. This is based on techniques of geostatistics used to calculate the autocorrelation that enters points of measurement. The advantage of this method is that it takes into account the specific space behavior of the studied variable (Alleaum et al., 2010). Lastly, these data made it possible to calculate the surface of the zone, its relative importance (\%), total volume $\left(\mathrm{m}^{3}\right)$, the maximum depth $(Z \max )$, the average depth (Zavrg) and the Zavrg/Zmax report/ratio.

\section{The physio-chemical measurement of the lakes water parameters}

At the time of the inventory, the physicochemical parameters for water of the lakes were measured at a depth of $0.5 \mathrm{~m}$ using a continuous multiSonde WTW MPP-350. The data relating to the temperature and conductivity at the time of the bathymetric survey was synchronized with GPS Map Garmin. Thereafter, using probe
WTW, the $\mathrm{pH}$, the temperature and conductivity were measured for the whole of the Lakes Ounianga Kebbir and Serir, as well as the surrounding sources.

\section{RESULTS AND DISCUSSION}

\section{Bathymetry and morphometry}

The detailed examination of the bathymetry of the Lake Yoan and Teli reveals a relatively complex basic morphology (Figure 3). The range of colors and the values of the isobaths highlight different provinces from the Lakes. For the Lake Yoan, three morphological types were identified: (a) the channel type (of direction -so) which meets in the zones of significant current sedimentation and corresponds to a depression located at the center of the lake with a maximum depth of $27.5 \mathrm{~m}$. In this zone, the contribution of sedimentation is supposed to be significant; (b) the beach, whose slope is located in zones of current sedimentary contributions and (c) between these two bathymetric profiles is observed intermediate morphological types that presents significant changes of inclines corresponding to the beach rock'n'rolls. As a whole, the depth decreases from the center towards the periphery of the lake. However, the highest depths $(28 \mathrm{~m})$ are observed mainly on level NNE of the lake and two other sections.

The Lake Téli, of rather lengthened form, which shows reliefs immersed in the form of hillock, testifies and presents five arms with small islands in the middle of the lake. The isobathic chart of the Lake Téli (Figure 3B) shows that the depths vary from 0 to $5.6 \mathrm{~m}$. The lowest 

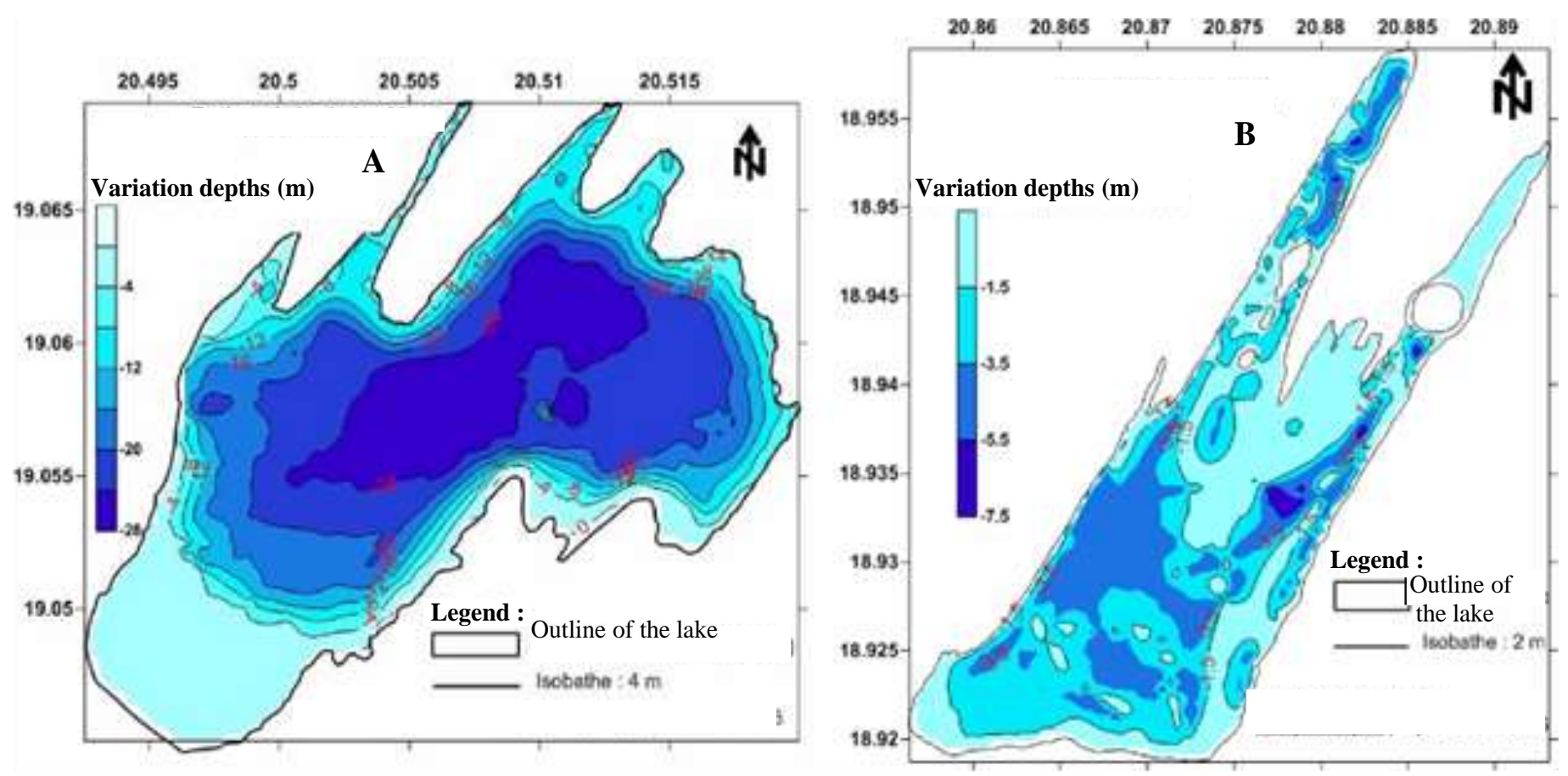

Figure 3. Bathymetry of (A) Lake Yoan and (B) Teli. Source of Data : GELT-2016

Table 1. Morphometric characteristics of the Lake Yoan and Teli

\begin{tabular}{lcc}
\hline Parameter & Lake Yoan & Lake Teli \\
\hline Surface area $\left(\mathrm{km}^{2}\right)$ & 3.58 & 4.4 \\
Total volume in $\left(\mathrm{m}^{3}\right)$ & 53822631.144 & 10262248.367 \\
$\mathrm{Z}=0$ & $\mathrm{~m}^{3}$ & $\mathrm{~m}^{3}$ \\
Average depth $(\mathrm{m})$ & 11.70 & 2.74 \\
Maximum depth $(\mathrm{m})$ & 27.51 & 5.55 \\
relation Zavrg/Zm ax & 0.42 & 0.49 \\
\hline
\end{tabular}

depths are observed on the parts of lake where they reach $5.6 \mathrm{~m}$ and the maximum depth located at the East of the lake is $5.6 \mathrm{~m}$ (Figure 3).

From morphological point of view, the difference between these two lakes is well marked initially by the form of which the first is conical and the other is lengthened. The lake Yoan is much deeper than that of Teli whose depth varies from 0 to $5.6 \mathrm{~m}$. The volume of water for the Lake Yoan is estimated as $53,822,631 \mathrm{~m}^{3}$ and for the Lake Teli as $10262248 \mathrm{~m}^{3}$ (Table 1 and Figures 4 and 5).

\section{Physio-chemistry of the lake water}

The various physicochemical parameters are also important when an evaluation of the quality of a water level is carried out in order to determine if it is favorable for a particular species. The water temperature influences the quantity of energy available for the biological productivity and the chemical processes in the lakes, including the quantity of dissolved oxygen which is essential for the maintenance of the aquatic life (Environnement Canada, 2011). Moreover, the thermal structure of the water of a lake can be conferred with increase in ecosystemic diversity. Certain species prefer hot water of the surface layer of the lake such as millers and the mudfish (Demers and Arvisais, 2011) while others prefer deeper cold water such as the burbots and salmonides. The temperature of the water of the Lake Teli measuring up to $0.5 \mathrm{~m}$ varies from 20.8 to $36^{\circ} \mathrm{C}$ and for the Lake Yoan it varies from 16.50 to $32.9^{\circ} \mathrm{C}$ (Figure $6)$. Water conductivity is a measurement of the resistance of an aqueous solution to an electric flux (Wetzel, 2001). It is a good indicator of the abundance of ions in water. The measurements of conductivity taken at the time of the bathymetric survey only deal with surface lakes. The chart of space distribution of conductivity is not 


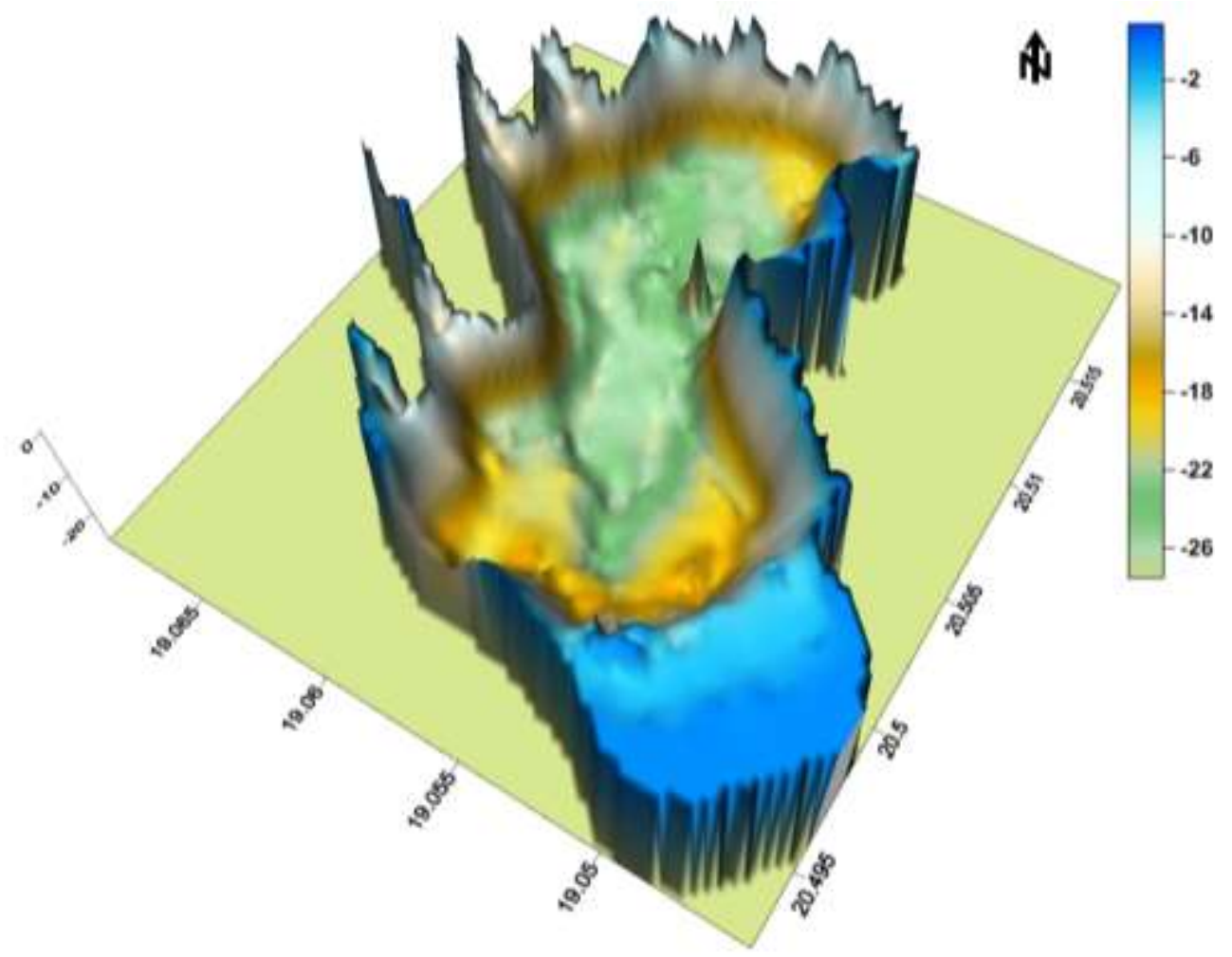

Figure 4. Digital elevation model of (A) Lake Yoan and (B) Teli.

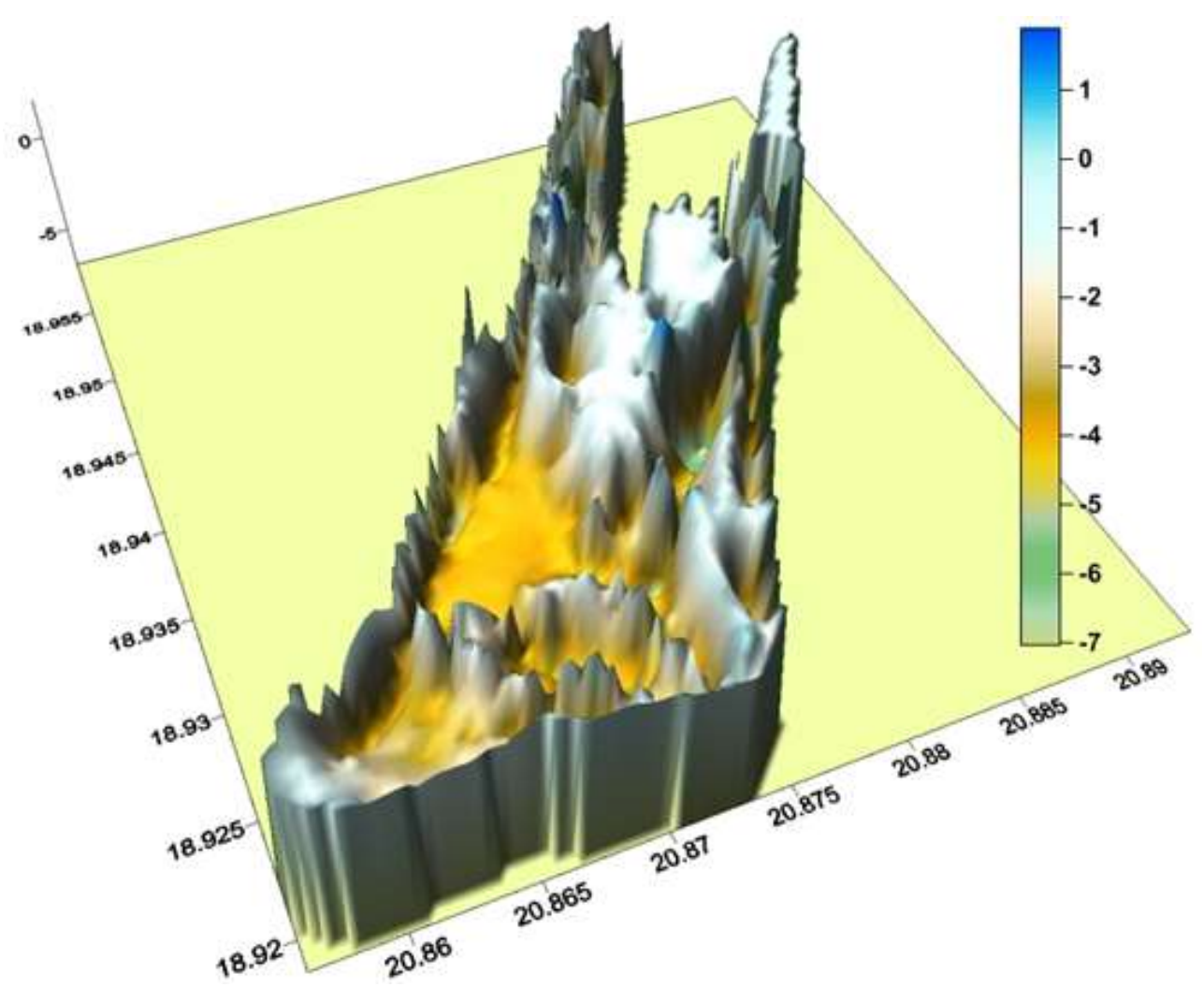

Figure 5. Digital elevation model of (A) Lake Yoan and (B) Teli. 


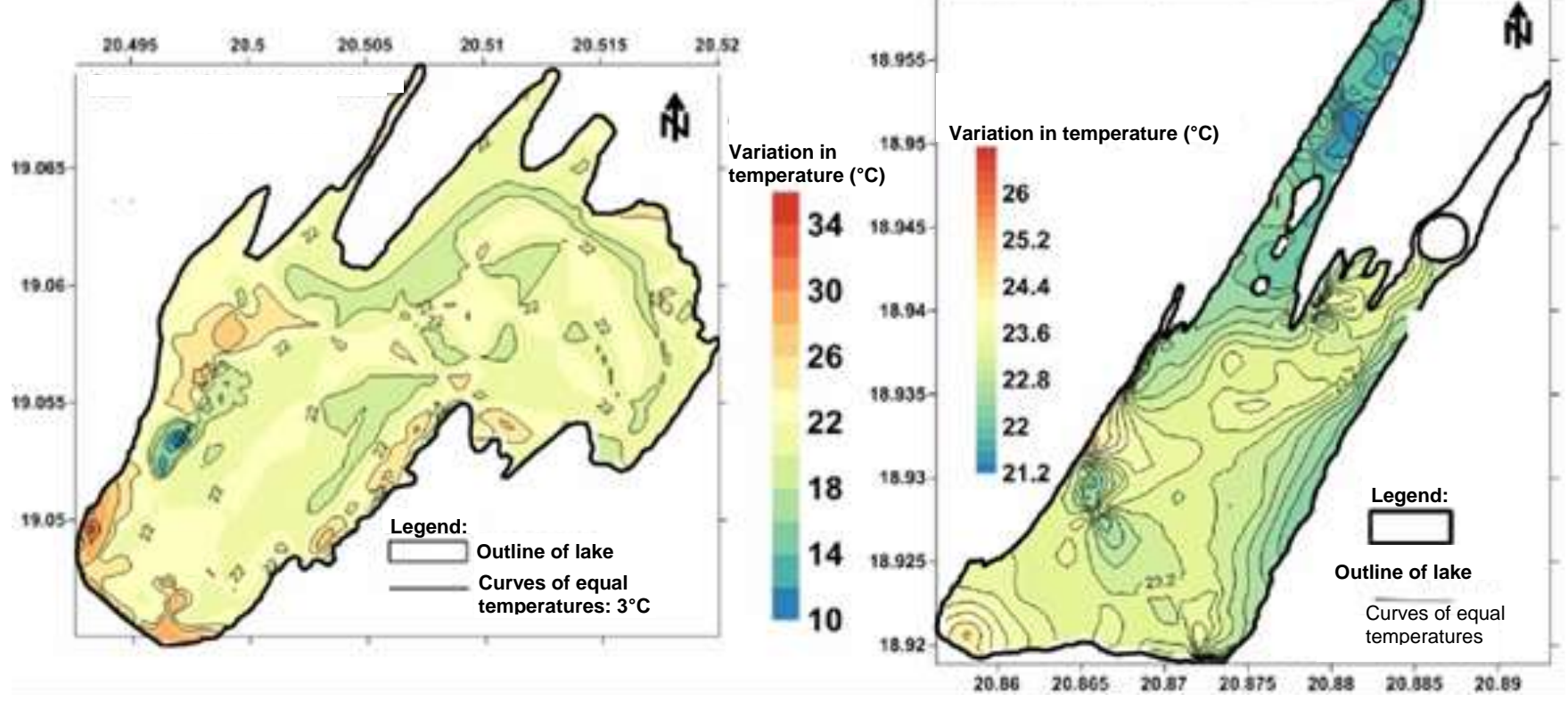

Figure 6. Variations in temperature of surface water of the Lakes Yoan and Teli.

Table 2. Physicochemical parameters of the Lakes of Ounianga, October 2016.

\begin{tabular}{|c|c|c|c|c|c|c|c|c|}
\hline \multirow{2}{*}{ Zone } & \multirow{2}{*}{ Lake } & \multicolumn{2}{|c|}{ Localisation } & \multirow{2}{*}{$\begin{array}{c}\text { Conductivity } \\
(\mu \mathrm{S} / \mathrm{CM})\end{array}$} & \multirow{2}{*}{$\begin{array}{c}\text { Surface } \\
\text { temperature }\left({ }^{\circ} \mathrm{C}\right)\end{array}$} & \multirow{2}{*}{$\mathrm{O}_{2}(\mathrm{mg} / \mathrm{l})$} & \multirow{2}{*}{$\mathrm{pH}$} & \multirow{2}{*}{ Altitude (m } \\
\hline & & Latitude & Longitude & & & & & \\
\hline \multirow{6}{*}{ O. Kebir } & Yoan & $19.802^{\circ} \mathrm{N}$ & $20.5554^{\circ} \mathrm{E}$ & 64000 & 26.36 & 9.84 & 9.92 & \\
\hline & Miodji & $19.01097^{\circ} \mathrm{N}$ & $20.51655^{\circ} \mathrm{E}$ & 72000 & 22.1 & 7.37 & 10.10 & 373 \\
\hline & Uma & $19.01143^{\circ} \mathrm{N}$ & $20.51597^{\circ} \mathrm{E}$ & 172000 & 24.3 & 4.32 & 9.72 & 373 \\
\hline & Forodone & $19.0051^{\circ} \mathrm{N}$ & $20.51597^{\circ} \mathrm{E}$ & 12860 & 21.5 & 0.03 & 9.56 & \\
\hline & Teli & $19.93333^{\circ} \mathrm{N}$ & $20.86667^{\circ} \mathrm{E}$ & 112100 & 25 & 3.80 & 9.74 & \\
\hline & Djabou & $19.0051^{\circ} \mathrm{N}$ & $20.5307^{\circ} \mathrm{E}$ & 165600 & 30.9 & 6.06 & 9.79 & 365 \\
\hline \multirow{9}{*}{ 0. Serir } & Os bokou & $18.91546^{\circ} \mathrm{N}$ & $20.91156^{\circ} \mathrm{E}$ & 326 & 23.3 & 6.43 & 7.77 & 356 \\
\hline & Bedrim & $18.91711^{\circ} \mathrm{N}$ & $20.90246^{\circ} \mathrm{E}$ & 737 & 19.4 & 0.74 & 8.03 & 352 \\
\hline & Djara & $18.91792^{\circ} \mathrm{N}$ & $20.89266^{\circ} \mathrm{E}$ & 1343 & 23.1 & 3.02 & 7.9 & 349 \\
\hline & Agouta & $19.12202^{\circ} \mathrm{N}$ & $20.88825^{\circ} \mathrm{E}$ & 1807 & 23.6 & 6.23 & 8.33 & 422 \\
\hline & Hogou & $18.92628^{\circ} \mathrm{N}$ & $20.88106^{\circ} \mathrm{E}$ & 1883 & 24.9 & 5.44 & 8.16 & \\
\hline & Ayou & $18.92958^{\circ} \mathrm{N}$ & $20.86019^{\circ} \mathrm{E}$ & 2880 & 22.5 & 4.32 & 8.74 & 300 \\
\hline & Edem (Petit) & $18.93094^{\circ} \mathrm{N}$ & $20.85452^{\circ} \mathrm{E}$ & 896 & 22.2 & 5.48 & 8.49 & 322 \\
\hline & Edem (Grand) & $18.93029^{\circ} \mathrm{N}$ & $20.85097^{\circ} \mathrm{E}$ & 678 & 23.7 & 5.91 & 8.60 & 345 \\
\hline & Source & & & & & & & \\
\hline \multirow{8}{*}{ Lake Yoan } & Source A1 (Ouroull) & $19.10604^{\circ} \mathrm{N}$ & $20.49286^{\circ} \mathrm{E}$ & 344 & 31.2 & 2.52 & 6.98 & \\
\hline & SourceA2 (Ourouli) & $19.10604^{\circ} \mathrm{N}$ & $20.49286^{\circ} \mathrm{E}$ & 403 & 31.2 & 2.19 & 6.88 & \\
\hline & Source B & $19.05329^{\circ} \mathrm{N}$ & $20.51059^{\circ} \mathrm{E}$ & 223 & 26.4 & & 7.34 & 414 \\
\hline & Source C & $19.05994^{\circ} \mathrm{N}$ & $20.49671^{\circ} \mathrm{E}$ & 378 & 31.1 & 2.30 & 7.02 & \\
\hline & Source D & $19.05909^{\circ} \mathrm{N}$ & $20.49629^{\circ} \mathrm{E}$ & 313 & 31 & 2.54 & 7.59 & 375 \\
\hline & Source E (Hoye) & $19.06838^{\circ} \mathrm{N}$ & $20.51174^{\circ} \mathrm{E}$ & 340 & 31.6 & 1.77 & 7.03 & 370 \\
\hline & Source F (Mogie) & $19.01015^{\circ} \mathrm{N}$ & $20.51649^{\circ} \mathrm{E}$ & 340 & 29.8 & 2.93 & 6.6 & 373 \\
\hline & Souece G (Yaki) & $19.05878^{\circ} \mathrm{N}$ & $20.52065^{\circ} \mathrm{E}$ & 215 & 24.1 & 2.44 & 7.59 & 373 \\
\hline
\end{tabular}

represented here because of their homogeneity on the whole of surface of the lakes. However, the result of in situ analysis shows that the highest conductivity is that of the Lake Teli with $111700 \mu \mathrm{S} / \mathrm{cm}$ followed by Lake UMA and Yoan with values 172000 and $64,000 \mu S / \mathrm{cm}$, respectively. The $\mathrm{pH}$ varies from 6.6 to 10 and dissolved oxygen varies from 0.03 to 9.92 . The results are consigned in Table 2. 


\section{Conclusion}

This study on the Lakes of Ounianga (Kébbir and Serir) could highlight morphology of the bottom of the Lakes (Yoan and Teli) and the physicochemical characteristics of the lakes water. The data from the bathymetric lifting was increased for the Lake Yoan, with three morphological standards: (a) the channel type (of direction - so), which corresponds to a depression located at the center of the lake where the contribution of sedimentation is supposed to be significant; (b) the beach, whose slope is relatively constant, located in zones of current sedimentary contributions and (c) between these two bathymetric profiles, with observed intermediate morphological types which presents significant changes of incline corresponding to the beach - rock'n'rolls. The Lake Teli is of rather lengthened form, with a relatively low depth than that of the Lake Yoan. This Lake shows the presence of several islands immersed under water with stiff slopes.

The in situ analyses of the physico-chemical parameters of the lakes water and sources show that the Lake Teli is more salted with a conductivity of 112100 $\mu \mathrm{S} / \mathrm{Cm}$ followed by Lake Uma and Yoan, respectively with conductivities of 172000 and $64000 \mu \mathrm{S} / \mathrm{Cm}$, respectively. The chart of space distribution of the temperature is less heterogeneous. The temperature of the water of the Lake Teli measuring up to $0.5 \mathrm{~m}$ varies from 20.8 with $36^{\circ} \mathrm{C}$, while for the Lake Yoan, it varies from 10.50 to $32.90^{\circ} \mathrm{C}$, with an average of $22.27^{\circ} \mathrm{C}$. The water $\mathrm{pH}$ of the Lakes Yoan and Teli is basic which is similar to the surrounding lakes.

This study contributes to improvement of knowledge of the great Lake ecosystems of Chad, precisely the Lakes of Ounianga. Bathymetric measurements made it possible to answer the questions of structure and depth variation of the lakes. However, for a better interpretation these data must be associated with the sedimentological data.

\section{CONFLICT OF INTERESTS}

The authors have not declared any conflict of interests.

\section{REFERENCES}

Alleaum S, Lanoisellee C, Agillier C (2010). Bathymétrie des plans d'eau: protocole d'échantillonnage et descripteurs morphométriques. Document de CEMAGREF. 24p.

Bragg OM, Duck RW, Rowan JS, Black AR (2003). Review of methods for assessing the hydromorphology of Lakes. vol. WFD06, Environment Agency, Edinburgh.
Van Bocxlaer B, Verschuren D, Schettler G, Krôpelin S (2011). Modem and early Holocene mollusk fauna of the Ounianga Lakes (northern Chad); implications for palaeohydrology of the central Sahara. J. Quat. Sci. 26:433-447.

Burgis MJ, Symoens JJ (1987). African wetlands and shallow water bodies/Zones humides et lacs peu profonds d'Afrique. Directory/Repertoire ORSTOM, Coll. Travaux et Documents $n^{\circ} 211$, Paris, 650p.

Capot-Rey R (1961). Bourkou et Ounianga, étude de géographie régionale. Institut de recherches sahariennes, Alger 5:182.

De Bortoli J, Argillier C (2006). Hydromorphologie lacustre, mesure de son altération et réponses biologiques - Etude bibliographique. Rapport d'étude CEMAGREF, Montpellier.

Demers A, Arvisais M (2011). Guide de normalisation des inventaires bathymétriques. Ministère des Ressources naturelles et de la Faune, Service de la faune aquatique, Québec. 32p.

Environnement Canada (2011). État du lac Winnipeg : de 1999 à 2007 . Faits saillants. http://www.ec.gc.ca/doc/publications/eauwater/COM1167/qualityqualite_f.htm.

Jungraithmayr H, Barreteau D, Seibert U (1997). L'homme et l'eau dans le bassin du lac Tchad. Paris. Paris: ORSTOM, 1997, 487 p. (Colloques et Séminaires). ISBN 2-7099-1373-9, pp. 469-474.

Hissene MA (1986). Geologie und Hydrogeologie des Erdis-Beckens, NE Tschad. Berliner geowiss. Abh. (A) 76:67.

INSEED (2012). Deuxième Recensement Général de la Population et de l'Habitat (RGPH2, 2009). www.inseedtchad.com/?Resultatsprovisoire-de-RGPH2-2009. 45p.

Kröpelin S (2007a). High-resolution climate archives in the Sahara (Ounianga, Chad). Atlas of Cultural and Environmental Change in Arid Africa. S. Cologne, pp. 56-57.

Kröpelin S (2007b). The Saharan Lakes of Ounianga serir (NE Chad): A unique hydrogeological system. Atlas of cultural and environ mental change in arid Africa. Afr. Prachistorica 11:54-55.

Kröpelin S, Verschuren D, Lézine AM, Eggermont $\mathrm{H}$, Cocquyt $\mathrm{C}$, Francus P, Cazet JP, Fagot M, Rumes B, Russell JM, Darius F, Conley DJ, Schuster M, Von Suchodoletz H, Engstrom DR (2008). Climate-driven ecosystem succession in the Sahara: the past 6000 years. Science 320:765-768.

Kuper R, Kröpelin S (2006). Climate Controlled Holocene Occupation in the Sahara: Motor of Africa's Evolution. Dans Sci. 313:803.

Ostendorp W (2004). New approaches to integrated quality assessment of Lakeshores. Limnologica 34:160-166.

Tubiana MJ (1997). Les lacs d'Ounianga et les Ounia. ORSTOM, Paris. P. 46.

UNESCO (2011). Proposition d'inscription des lacs d'Ounianga sur la liste du patrimoine mondial. Dossier d'inscription. 327p.

Wetzel RG (2001). Limnology Lake and River Ecosystems. Third edition, Academic Press, San Diego. 1006p.

Wolff JP (1964). Carte Géologique de la République de Tchad. Bureau de Recherches Géologiques et Minières: Orleans, France: Editions du BRGM 209:1992. 